\title{
PENGGUNAAN GOOGLE CLASSROOM UNTUK PENINGKATAN PEMBELAJARAN ONLINE BAGI GURU-GURU UPTD SMPN 11 KUPANG
}

\author{
Molina Olivia Odja1), Wenefrida T. Ina1), Stephanie I. Pella1), Frans J. Likadja1) \\ 1)Program Studi Teknik Elektro, Fakultas Sains dan Teknik, Universitas Nusa Cendana, Kupang, NTT, Indonesia \\ Corresponding author: Molina Olivia Odja \\ E-mail : molina.odja@staf.undana.ac.id
}

Diterima 11 November 2021, Disetujui 28 November 2021

\begin{abstract}
ABSTRAK
Kompetensi dan keahlian dalam menggunakan Teknologi Informasi dan Komunikasi (TIK) sangat penting terutama bagi tenaga pendidik seperti guru maupun dosen yang tugasnya sangat mulia yaitu untuk mencerdaskan kehidupan anak bangsa. Persoalan yang dihadapi oleh guru-guru pada UPTD SMP Negeri 11 Kota Kupang adalah belum memanfaatkan aplikasi google classroom dalam melakukan Pendidikan Jarak Jauh (PJJ) selama masa pandemic dengan efektif agar proses Kegiatan Belajar Mengajar (KBM) dapat tetap dilaksanakan, dengan memanfaatkan fitur-fitur yang tersedia seperti memudahkan pengajar dan murid untuk berinteraksi baik di dalam sekolah maupun di luar sekolah, penghematan kertas (paperless) dan waktu. Berdasarkan alasan tersebut, maka dibuatlah kegiatan pengabdian dengan judul "Pelatihan Google Classroom bagi Guru-Guru UPTD SMP Negeri 11 Kota Kupang". Adapun tahapan yang digunakan adalah melalui tahap persiapan, pelaksanaan kegiatan dengan metode pelatihan dan pendampingan. Kegiatan dapat berjalan dengan efektif dan efisien hal ini dibuktikan dengan antusias peserta yang mengikuti pelatihan dengan mendapatkan semua materi yang sudah dipersiapkan dan sesuai dengan jadwal yang sudah ditetapkan. Pendampingan secara online melalui grup whatsapp yang telah dibentuk, dengan tujuan untuk kedalaman pemahaman materi melalui pemberian tugas serta diskusi dan sebagai bentuk tanggung jawab moril. Kegiatan PKM ini sangat diapresiasi oleh para peserta dengan mengikuti kegiatan pelatihan dari awal sampai akhir.
\end{abstract}

Kata kunci: google classroom; pembelajaran; online; guru-guru.

\begin{abstract}
Competence and expertise in using Information and Communication Technology (ICT) are very important, especially for educators such as teachers and lecturers whose very noble task is to educate the lives of the nation's children. The problem faced by teachers at UPTD SMP Negeri 11 Kupang City is that they have not used the google classroom application in conducting Distance Education (PJJ) during the pandemic effectively so that the Teaching and Learning Activities (KBM) process can continue to be implemented, by utilizing the features such as making it easier for teachers and students to interact both inside and outside school, saving paper (paperless) and time. Based on these reasons, a service activity was made with the title "Google Classroom Training for UPTD Teachers at SMP Negeri 11 Kupang City". The stages used are through the preparation stage, implementation of activities with training and mentoring methods. Activities can run effectively and efficiently, this is evidenced by the enthusiasm of the participants who participated in the training by getting all the materials that had been prepared and according to the schedule that had been set. Online assistance through WhatsApp groups has been formed, with the aim of deepening understanding of the material through assignments and discussions and as a form of moral responsibility. This PKM activity was highly appreciated by the participants by participating in training activities from beginning to end.
\end{abstract}

Keywords: google classroom; learning; online; teachers.

\section{PENDAHULUAN}

Dimasa pandemi ini, dimana sudah memasuki tahun ke-2 yang berdampak pada kegiatan disegala bidang dilakukan dari rumah dan juga melalui media online. Hal ini dilakukan untuk mencegah penyebaran Covid-19. Selain instansi perkantoran, lembaga pendidikan juga melakukan kegiatan belajar mengajar secara daring (dalam jaringan) atau PJJ (Pendidikan Jarak jauh). Dengan peralihan dari mengajar secara tatap muka dikelas dengan pengajaran secara online, memaksa para guru 
berpengalaman untuk keluar dari zona nyaman mereka. Para guru harus menghadapi keterampilan dan teknik baru dengan sedikit atau tanpa waktu persiapan.

Saat ini ada banyak tersdia platform pendidikan yang digunakan untuk proses belajar mengajar dan ditawarkan baik gratis maupun berbayar. Salah satu yang paling banyak digunakan dan terkenal adalah Google Classroom.

Google Classroom memberikan manfaat diantaranya selalu menghadirkan teknologi baru, praktis dan mudah diakses, efisiensi dalam pembelajaran baik dari segi waktu dan hemat biaya, murid menjadi mandiri, tersedianya fitur-fitur yang mudah untuk digunakan, belajar bisa dimana dan kapanpun tanpa dibatasi oleh ruang dan waktu, serta menjadi tempat bagi guru dan murid untuk berinteraksi dan diskusi.

Adapun fitur-fitur yang disediakan oleh google classroom yaitu :

1. Assigment (Penugasan)

Fitur ini memungkinkan para guru atau pengajar untuk memberikan materi maupun tugas berupa, teks, gambar, video, dan lainlain kepada siswa.

2. Konferensi Online

Dengan bantuan google meet, pengajar dapat menyampaikan materi secara langsung yang dikenal dengan virtual meeting dengan siswa.

3. Single view

Untuk melihat perkembangan tugas yang diberikan ke siswa serta melakukan penilaian, dan siswa juga dapat melihat tugas-tugas yang diberikan oleh guru.

4. Penyusunan Kelas Online

Kemudahan bagi seorang pengajar atau guru untuk mengorganisir banyak kelas.

5. Penilaian Langsung

Siswa dapat segera memperoleh nilai jika sudah diperiksa oleh guru.

6. Announcement (Pengumuman)

Berfungsi untuk memberikan informasi kepada siswa, misalnya jadwal pelaksanaan ujian, batas pengumpulan tugas, dan lainlain.

7. Transfer Kelas

Kelas dapat dipindahtangankan ke pengajar atau guru lain serta dapat mengakses semua kegiatan yang sudah dilakukan.

8. Integrasi Kelas

Dapat dihubungkan dengan aplikasi lain seperti Quizizz, Code.org, dan lain sebagainya sehingga kelas menjadi menarik dan menyenangkan.

9. Google Formulir

Fitur ini membuat pengajar dapat memberikan penilaian secara real time dan menjamin semua tugas diperiksa dan siswa mendapatkan nilai atau skor.

Berdasarkan sejumlah manfaat dan fitur yang ditawarkan, maka aplikasi ini sangat membantu para guru untuk melakukan pembelajaran secara online yang selama ini terhalang oleh kondisi pandemi Covid-19. Aplikasi ini sangat mudah dioperasikan dan ada versi gratis maupun berbayar.

UPTD SMP Negeri 11 Kota Kupang yang beralamat di kelurahan Naimata, kecamatan Maulafa kota Kupang yang bergerak di bidang pendidikan. Untuk tetap mempertahankan atau meningkatkan kualitas pembelajaran dimasa pandemi ini juga dituntut untuk tetap menjalankan Pembelajaran Jarak Jauh (PJJ) agar proses Kegiatan Belajar Mengajar (KBM) terus berjalan dengan efektif, oleh karena itu para guru dituntut untuk terus mengasah ketrampilan selain dalam mengajar konvensional juga melalui pemanfaatan Teknologi Informasi dan Komunikasi (TIK), untuk itu kegiatan-kegiatan penguasaan TIK perlu dilakukan melalui kegiatan pelatihan baik yang diadakan oleh sekolah maupun pihak lain baik tatap muka atau mengikuti pelatihan yang dilakukan secara daring yang semakin marak disaat pandemi ini. Menjawab tantangan ini, maka diadakan pelatihan bagi guru-guru UPTD SMP Negeri 11 kota Kupang tentang penggunaan Google Classroom.

\section{METODE}

Metode yang digunakan pada kegiatan pelatihan penggunaan google classroom sebagai upaya untuk peningkatan pembelajaran online bagi guru-guru di UPTD SMP Negeri 11 Kupang adalah sebagai berikut :

1. Tahap Persiapan

a. Survey

Diawali dengan melakukan survey ke mitra yakni UPTD SMP Negeri 11 kelurahan Naimata, kecamatan Maulafa kota Kupang.

b. Identifikasi masalah

Mengidentifikasi permasalahan terhadap para guru yang akan mengikuti pelatihan sekaligus untuk mandapatkan data awal sebagai acuan untuk pembuatan materi pelatihan google classroom.

c. Studi literatur Melakukan studi literatur tentang google classroom.

d. Penyusunan materi

Materi yang akan dibuat terdiri dari pengertian serta fungsi google classroom dalam menunjang proses belajar mengajar yang diperoleh dari internet dan berbagai sumber lainnya. 


\section{Tahap Pelaksanaan}

a. Metode pelatihan

Untuk meningkatkan kemampuan para guru dalam mengoperasikan aplikasi Google Classroom, maka kegiatan akan dilakukan dengan metode ceramah dan tutorial atau praktek.

b. Metode Pendampingan

Metode pendampingan dimaksudkan untuk mengetahui sejauhmana para guru memanfaatkan program aplikasi Google Classroom seperti melakukan pembagian materi dan tugas, proses berjalan dengan lebih cepat dan tanpa hambatan dokumen fisik, koordinasi dan kerjasama antara guru dan murid dapat ditingkatkan, tempat penyimpanan bersama yang dapat diakses sesuai kepentingan tanpa resiko kerusakan data fisik dan bencana alam, Guru dapat memberikan update informasi dan materi secepatnya, dan dapat dimanfaatkan oleh siswa pada saat itu juga. Metode pendampingan dapat dilakukan secara langsung (Tim Pelaksana mengunjungi kedua mitra) dan melalui grup media sosial seperti Whatsapp.

\section{Tahap Evaluasi}

Pada tahapan evaluasi dilakukan untuk mengetahui tingkat keberhasilan dari kegiatan PKM yang dilaksanakan, sehingga dapat meminimalisir kendala-kendala atau kekurangan untuk kesempurnaan kegiatan berikutnya. Adapun pelaksanaan evaluasi yang dilakukan dilakukan meliputi:

a. Pemberian tugas mandiri untuk mengasah pemahaman.

b. Penyusunan laporan akhir sebagai bentuk pertanggung jawaban atas kegiatan yang dilakukan.

\section{HASIL DAN PEMBAHASAN}

Kegiatan Pengabdian ini dilaksanakan pada tanggal 16 September 2021. Dimulai pada pukul 08:00-15:00 WITA yang bertempat di SMPN 11 Kota Kupang.

Adapaun tahapan pelaksanaan kegiatan pengabdian masyarakat melalui skim Program Kemitraan Masyarakat (PKM) dengan judul "Penggunaan Google Classroom Untuk Peningkatan Pembelajaran Online Bagi GuruGuru UPTD SMP Negeri 11 Kupang", dijelasakan sebagai barikut.

Sebelum melakukan pelatihan, para guru dan panitia atau tim pelaksana kegiatan diwajibkan untuk mematuhi protokol kesehatan yang telah ditetapkan dengan mencuci tangan, mengecek suhu tubuh, menggunakan masker dan menjaga jarak.
Kegiatan ini diawali dengan doa yang dipimpin oleh salah seorang guru peserta dengan memohon rahmat dan perlindungan Tuhan sumber ilmu pengetahuan agar kegiatan ini dapat berjalan dengan baik dari awal hingga akhir (Gambar 1).

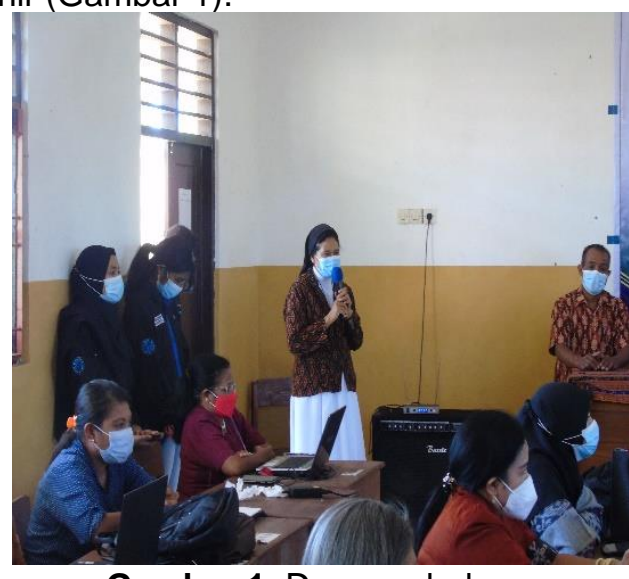

Gambar 1. Doa pembukaan

Acara dilanjutkan dengan memberikan kesempatan kepada mitra yang dalam hal ini kepala sekolah SMP N 11 Kupang untuk memberikan sambutan, dalam sambutannya berisi ungkapan menyambut baik kegiatan ini dan memberikan motivasi kepada para guru agar bisa mengikuti kegiatan ini dengan penuh semangat, sehingga materi dapat terserap dengan baik (Gambar 2).

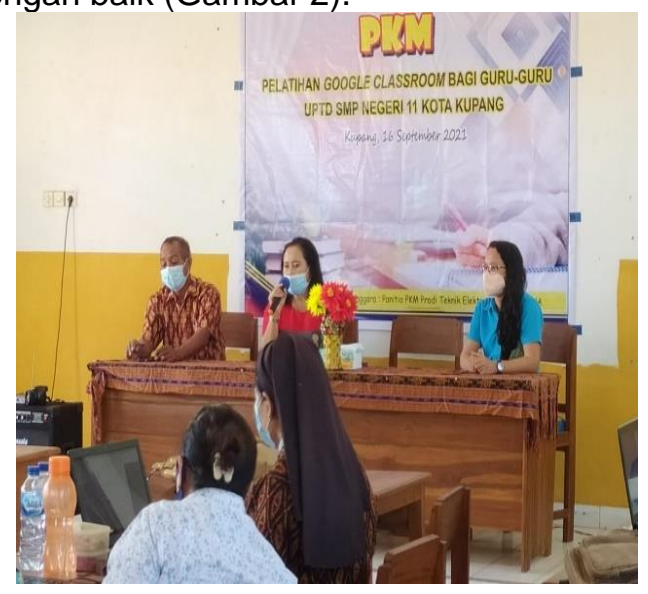

Gambar 2. Sambutan oleh kepala sekolah UPTD SMP Negeri 11 Kota Kupang

Dilanjutkan dengan sambutan dari Ketua Pelaksana PKM sekaligus membuka kegiatan (Gambar 3). 


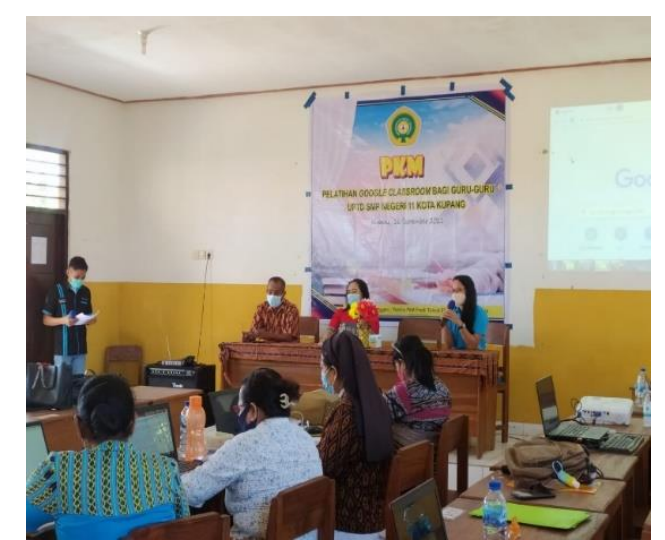

Gambar 3. Pembukaan kegiatan oleh Ketua Pelaksana PKM

Pada sesi pertama pemberian materi melalui ceramah dan praktek tentang bagaimana mengelola kelas di google classroom, seperti membuat dan bergabung dikelas baru. Membuat soal dengan google form (Gambar 4).

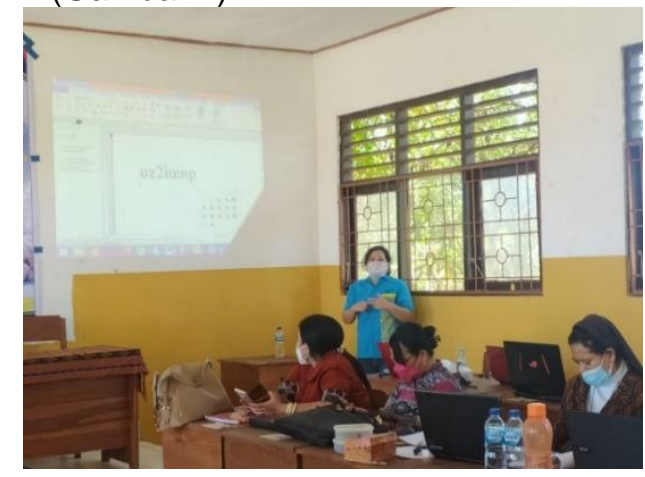

Gambar 4. Pemaparan materi I

Pada sesi kedua pemberian materi tentang bagaimana mengelola topik di google classroom, dengan metode ceramah dan praktek. Adapun sub materi yang disajikan adalah membuat daftar hadir, memeriksa dan mengembalikan hasil pekerjaan siswa, mengunggah file materi dari folder, dan mengambil materi dari google drive dan youtube (Gambar 5).

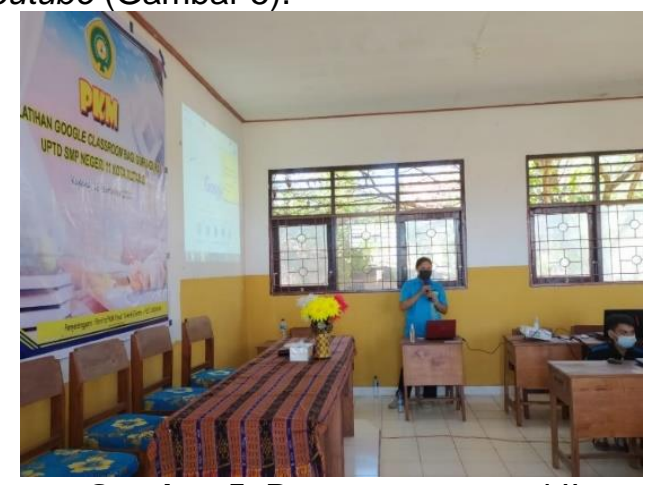

Gambar 5. Pemaparan materi II
Tahap selanjutnya adalah praktek penggunaan google classroom instruktur atau pemateri menjelaskan bagaimana mengoperasikan google classroom, dan membantu membuat akun bagi guru-guru yang belum memilikinya.

Langkah-langkah pembuatan akun di google classroom (bagi yang belum mempunyai email dengan domain gmail maka harus membuatnya terlebih dahulu), jika sudah maka dapat langsung mengikuti proses berikut ini :

1. Pada search engine ketikkan "google classroom" lalu pilih "Google Classroom" atau dengan mengetik https://classroom.google.com pada url atau web browser (Gambar 6).

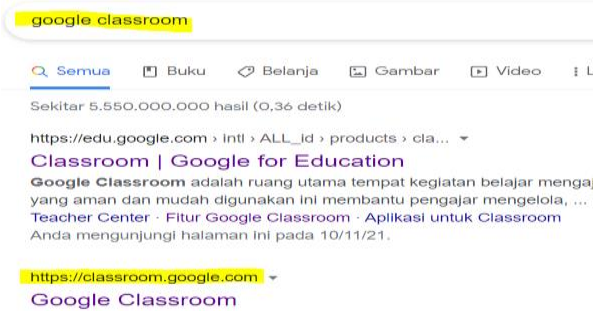

Gambar 6. Pencarian google classroom

2. Maka akan muncul tampilan seperti pada Gambar 7, kemudian masukkan akun gmail anda (jika sebelumnya sudah pernah melakukan login) lalu tekan tombol berikutnya, masukkan password dan tekan tombol berikutnya, maka akan tampil seperti Gambar 8

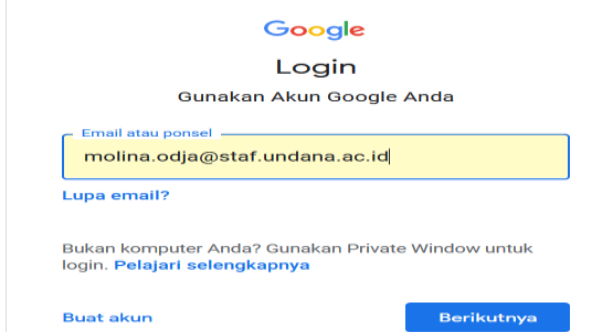

Gambar 7. Jendela login akun

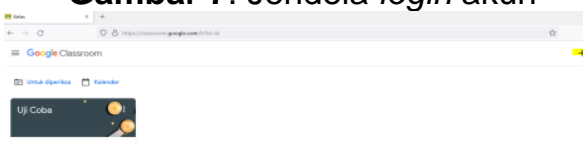

Gambar 8. Tampilan google classroom

Praktek membuat kelas baru atau bergabung ke kelas yang sudah ada, Langkahlangkahnya sebagai berikut :

1. Setelah berhasil login menggunakan akun anda.

2. Lihat tanda plus (+) pada Gambar 9, klik tombol tersebut untuk membuat kelas baru maka klik Buat Kelas, maka akan tampil 
seperti Gambar 10, isikan sesuai kebutuhan lalu klik tombol Buat.

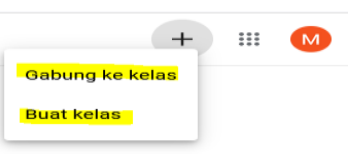

Gambar 9. Tampilan jendela buat kelas

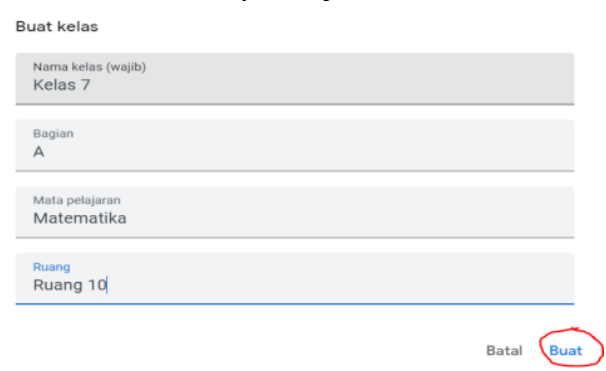

Gambar 10. Pengisian buat kelas

Setelah klik tombol Buat, maka akan tampil seperti Gambar 11, dengan demikian pembuatan kelas telah berhasil.

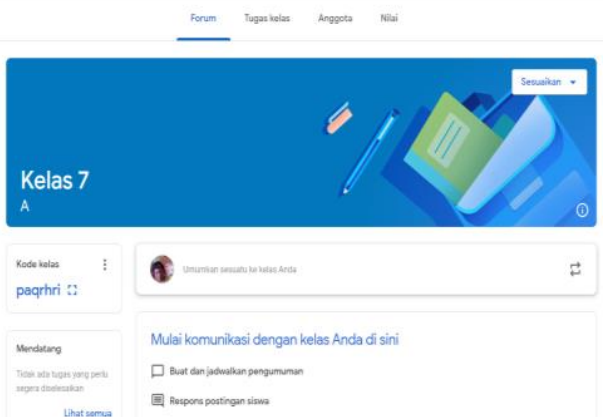

Gambar 11. Pembuatan kelas baru

Praktek gabung ke kelas yang sudah ada, Langkah-langkahnya sebagai berikut :

1. Setelah berhasil login menggunakan akun anda

2. Klik Gabung ke kelas, dengan mengklik tombol (+) seperti pada Gambar 9., maka akan tampil seperti Gambar 12. Siswa atau murid yang ingin bergabung harus mendaptkan Kode kelas terlebih dahulu dengan meminta pada guru kelas tersebut.

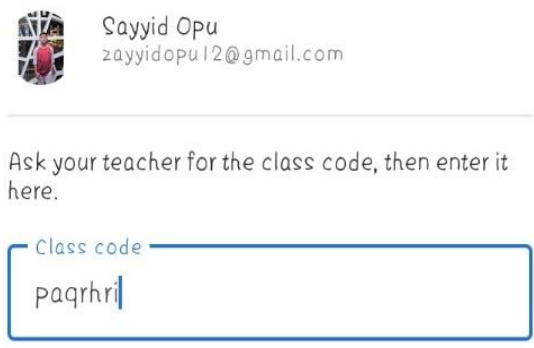

Gambar 12. Pengisian kode kelas

3. Setelah memasukkan Kode kelas lalu klik tombol Gabung disudut kanan atas, maka akan tampil seperti Gambar 13. yang berarti siswa berhasil gabung pada kelas tersebut.

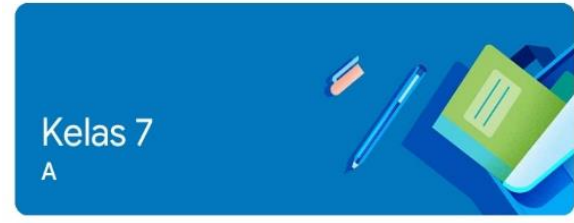

Share with your class...

Gambar 13. Tampilan gabung kelas pada jendela siswa

4. Setelah siswa berhasil gabung, maka pada tampilan google classroom guru akan terlihat seperti Gambar 14. Untuk mengeceknya dapat menekan tombol Anggota.

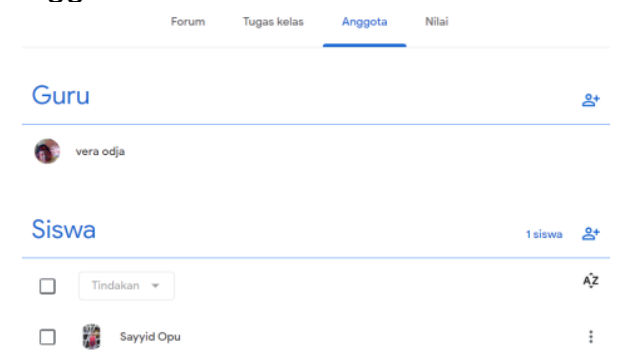

Gambar 14. Tampilan gabung kelas pada jendela Guru

Praktek membuat soal dengan google form, berikut Langkah-langkahnya :

1. Buka google form dengan mengetikkan pada search engine maka akan tampil jendela, setelah itu klik tanda (+), maka akan tampil seperti Gambar 15.

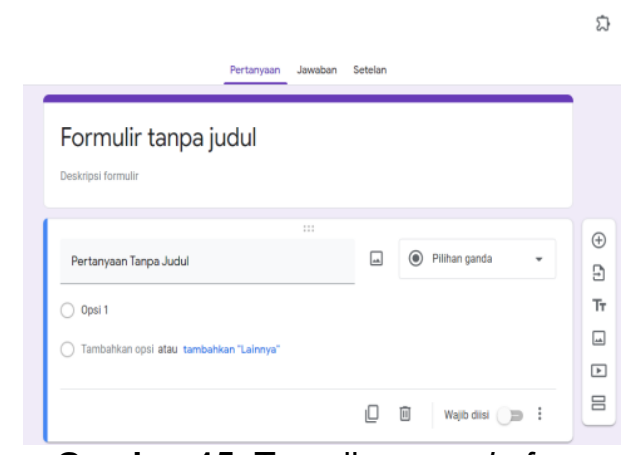

Gambar 15. Tampilan google form

2. Berikan judul pada form yang sudah dibuat. Biasa berisi tentang penjelasan singkat yang berkaitan dengan form yang dibuat.

3. Buat pertanyaan yang diinginkan. Dalam tahapan ini terdapat beberapa pilihan model jawaban, seperti pilihan ganda, pilihan jawaban singkat yang tidak membutuhkan sebuah penjelasan, pilihan kotak centang, pilihan drop down dan pilihan paragraf bagi pertanyaan yang membutuhkan sebuah deskripsi (Gambar 16). 


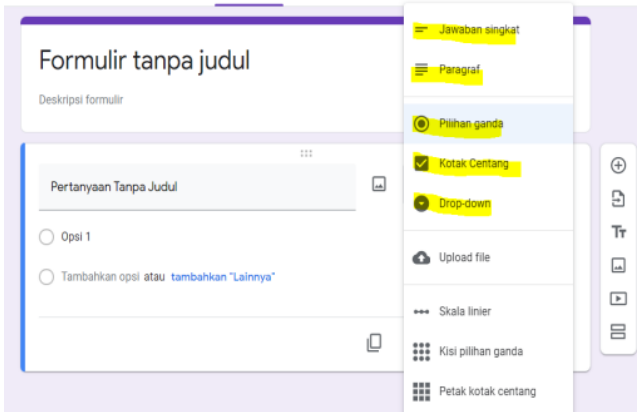

Gambar 16. Tampilan pilihan model jawaban pada google form

Praktek membuat daftar hadir atau absensi dengan google form, berikut Langkahlangkahnya :

1. Buka google form, lalu klik ikon plus dan form baru akan terbuka.

2. Berikan judul atau deskripsi singkat mengenai form yang sudah dibuat (Gambar $17)$.

\section{Daftar Hadir kelas A}

Gambar 17. Tampilan judul daftar hadir

3. Buat kolom nama siswa, lalu klik pada kolom dibawah judul. Pada tahap ini, gunakan pilihan pertanyaan sesuai dengan kebutuhan seperti yang telah dijelaskan (Gambar 18).

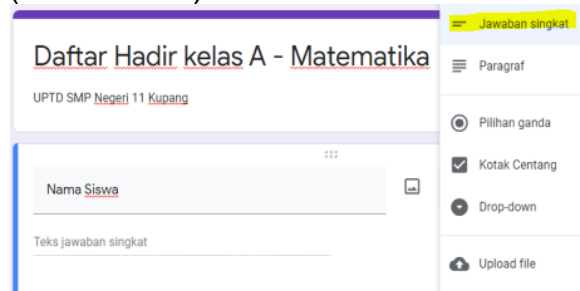

Gambar 18. Tampilan daftar hadir pada google form

Praktek pemeriksaan

dan pengembalian jawaban siswa dengan google classroom (Gambar 18), berikut Langkahlangkahnya :

1. Buka kelas yang diinginkan pada google classroom.

2. Kemudian klik menu Nilai seperti pada Gambar 19.

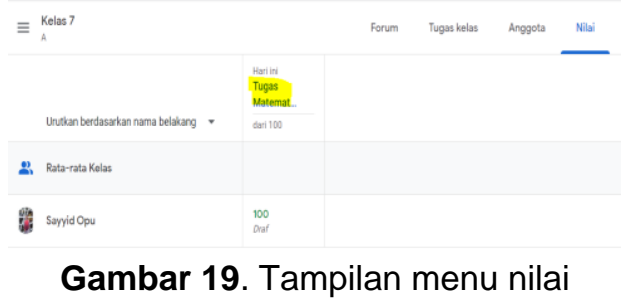

3. Klik Tugas Matematika (sebagai contoh), maka akan tampil seperti Gambar 20.

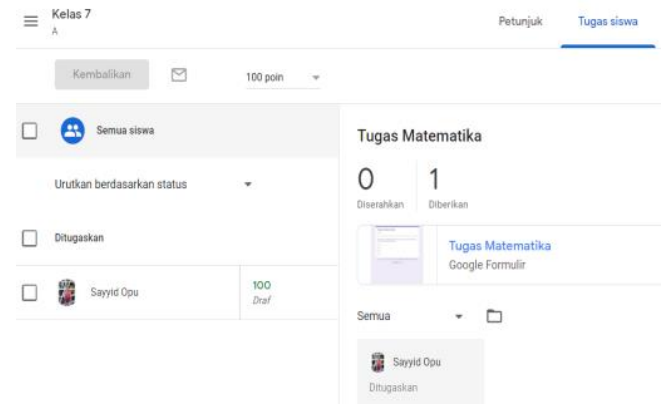

Gambar 20. Tampilan pemeriksaan nilai

4. Setelah guru memeriksa lalu memberikan nilai sesuai jawaban benar.

5. Guru dapat langsung mengembalikan hasil pekerjaan siswa dengan cara klik ikon Kembalikan pada halaman google classroom (Gambar 21).

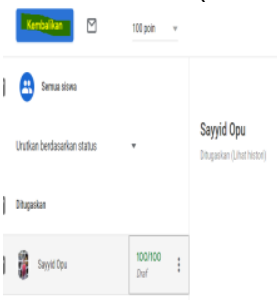

Gambar 21. Tampilan penilaian pada google classroom

Praktek mengunggah file materi dari folder, berikut Langkah-langkahnya:

1. Buka google classroom kemudian pilih menu tugas kelas pada bagian atas lalu klik ikon plus (Gambar 22).

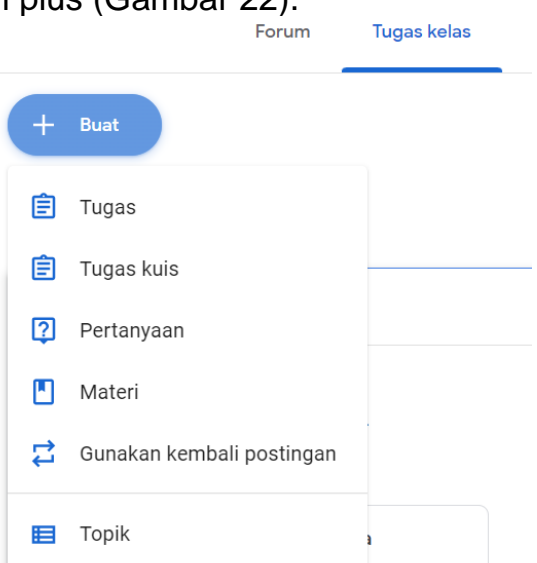

Gambar 22. Tampilan menu tugas kelas

2. Pilih menu materi kemudian beri judul terkait file materi yang akan diunggah.

3. Klik ikon upload lalu pilih lokasi folder materi yang akan diunggah.

4. Pilih file yang akan diunggah kemudian klik open (Gambar 23).

5. Klik posting pada bagian kanan atas. 


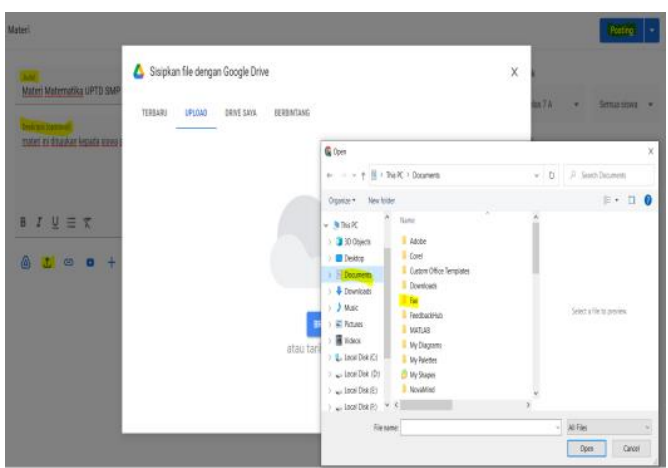

Gambar 23. Tampilan menggunggah file dari google drive

Praktek mengambil materi dari google drive dan youtube (Gambar 24), berikut Langkah-langkahnya:

1. Buka google classroom kemudian pilih menu tugas kelas pada bagian atas lalu klik ikon plus.

2. Pilih menu materi kemudian beri judul dan deskripsi terkait file materi yang akan diunggah.

3. Klik ikon google drive dan youtube lalu pilih file yang ingin diambil.

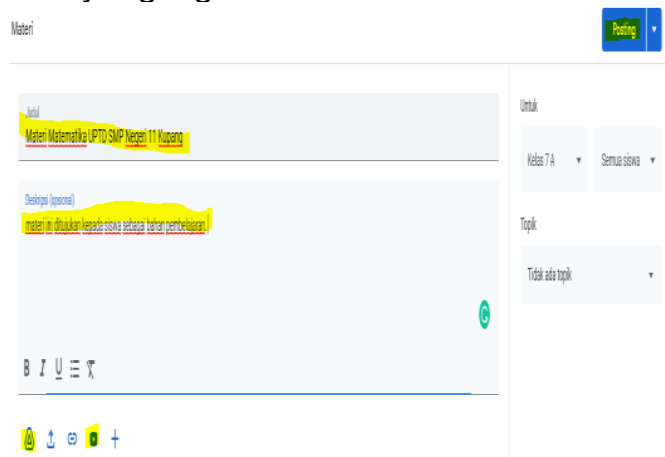

Gambar 24. Tampilan mengambil file dari google drive dan youtube

Para guru juga didampingi untuk membuat dan memasukkan tugas serta waktu pengumpulan tugas tersebut. Dilatih bagaimana cara melihat tugas yang sudah dikumpulkan dan yang belum mengumpulkan tugas serta cara memberikan nilai pada tugas yang sudah dikumpulkan, membuat absensi untuk siswa. (Gambar 25).

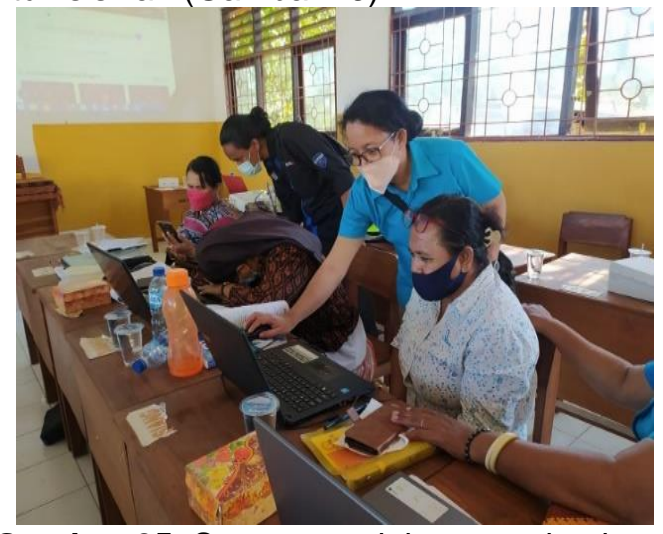

Gambar 25. Suasana pelaksanaan kegiatan
Pada kegiatan ini para guru juga diajarkan untuk langsung mempraktekan cara membuat dan menetapkan waktu, tanggal live meeting sehingga berdasarkan waktu dan tanggal yang telah dibuat para guru dan siswa dapat bertatap muka secara daring.

Berdasarkan hasil kegiatan yang telah dilakukan para guru dapat menggunakan aplikasi Google Classroom tetapi tidak semua mampu mengoperasikan dengan baik karena selama ini para guru hanya melakukan tatap muka secara langsung dan juga terdapat guru yang sudah berusia lanjut (lansia) sehingga tidak dapat menggunakan aplikasi Google Classroom dengan baik.

Pada kegiatan ini membawa dampak yang positif bagi para guru karena dapat dengan mudah memahami cara penggunaan aplikasi Google Classroom untuk kegiatan belajar mengajar secara online.

Sebelum kegiatan ini dilakukan, masih ada beberapa guru di SMPN 11 Kupang selama pembelajaran menggunakan whatsapp sebagai media yang dimana tidak bisa mengkoordinasi kelas lebih efisien. Selain itu peserta didik juga kurang memahani pembelajaran yang dilakukan melalui whatsapp.

Dibagian penutup dibagi atas dua sesi yaitu sesi foto bersama (Gambar 26 dan Gambar 27) dan uangkapan terima kasih dari kedua belah pihak .
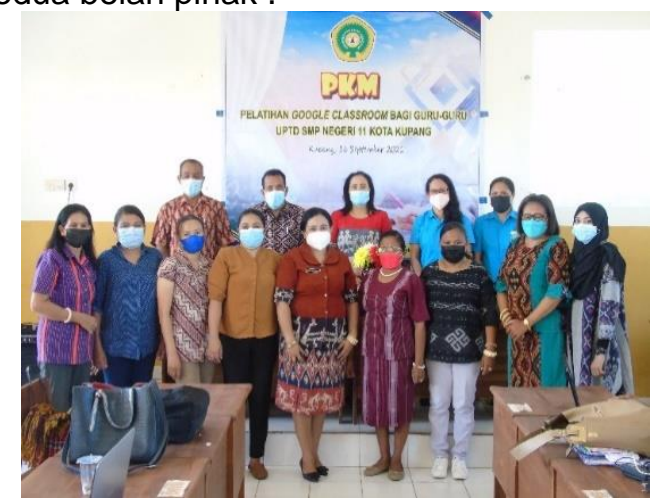

Gambar 26. Foto bersama peserta

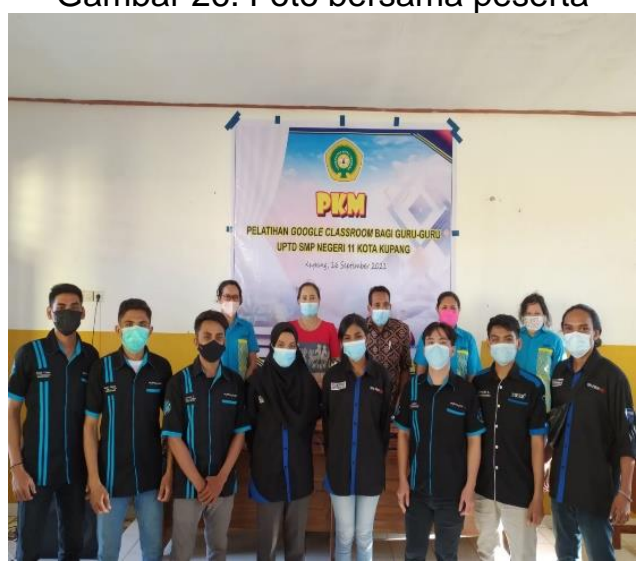

Gambar 27. Foto Bersama panitia 


\section{SIMPULAN DAN SARAN}

Kegiatan pengabdian kepada masyarakat melalui skim PKM dengan judul "Pelatihan Google Classroom bagi Guru-Guru UPTD SMP Negeri 11 Kota Kupang" dapat berjalan dengan efektif dan efisien hal ini dibuktikan dengan antusias peserta yang mengikuti pelatihan dengan mendapatkan semua materi yang sudah dipersiapkan dan sesuai dengan jadwal yang sudah ditetapkan.

Selanjutnya dilakukan pendampingan secara online melalui grup whatsapp yang telah dibentuk, dengan tujuan untuk kedalaman pemahaman materi melalui pemberian tugas serta diskusi dan sebagai bentuk tanggung jawab moril. Kegiatan PKM ini sangat diapresiasi oleh para peserta dengan mengikuti pelatihan dari awal sampai akhir kegiatan.

\section{UCAPAN TERIMAKASIH}

Terima kasih diucapkan kepada pihakpihak yang telah berpartisipasi dalam pelaksanaan program PKM ini, diantaranya:

Dekan Fakultas Sains dan Teknik, melalui sumber dana DIPA Universitas Nusa Cendana Tahun Anggaran 2021 melalui Surat Perjanjian Pelaksanaan Pengabdian Nomor : 60/UN15.15.2.PPK/SPP/FST/IV/2021.

Kepala sekolah UPTD SMP Negeri 11 Kota Kupang beserta Guru-guru yang menjadi peserta pelatihan pemanfaatan Google Classroom ini.

\section{DAFTAR RUJUKAN}

Eudeka, (2021). 7 Manfaat Google Classroom Untuk Pembelajaran Daring. Diambil dari https://www.eudeka.id/7-manfaatgoogle-classroom-untukpembelajaran-daring/

Nurfadhela, F. (2021). Tata Cara Membuat Google Classroom dan Fitur-Fiturnya. Diambil dari https://www.duniadosen.com/caramembuat-google-classroom/

Shandy, D. (2020). Cara Membuat Akun Google Classroom dengan Mudah. Diambil dari https://www.pusatilmupengetahuan.co m/cara-membuat-akun-googleclassroom-dengan-mudah/

Febriansyah. (2021). Cara Membuat Soal Online Menggunakan Google Forms untuk Guru-Siswa. Diambil dari https://tirto.id/cara-membuat-soalonline-menggunakan-google-formsuntuk-guru-siswa-eKCW

Tecno \& Sains. (2020). Cara membuat Google form untuk absensi siswa. Diambil dari https://kumparan.com/berita- terkini/cara-membuat-google-formuntuk-absensi-siswa-1uYp1UcVQuK/4 